\title{
Sistem Informasi Sebaran Data Alumni Berbasis Website GIS (Geographic Information System) pada Politeknik Sains dan Teknologi Wiratama Maluku Utara
}

\author{
Lia Muawarsiati ${ }^{1}$, Hindun hasan $^{2}$, Muhdar Abdurahman $^{3}$, Syahril Hasan $^{4}$ \\ Prodi Manajemen Informatika \\ Politeknik Sains Dan Teknologi Wiratama Maluku Utara \\ ${ }^{3}$ Prodi Manajemen Informatika, Akademi Ilmu Komputer (AIKOM) Ternate \\ lia.muarsiati@gmail.com
}

\begin{abstract}
Sistem Informasi Persebaran Data Alumni Berbasis Website GIS (Geographic Information System) Pada Politeknik Sains dan Teknologi Wiratama Maluku Utara.Politeknik Sains dan Teknologi Wiratama Maluku Utara merupakan kampus Swasta yang berlokasi di Kota Ternate, Kelurahan Jati Ternate Selatan, yang setiap tahun memiliki lulusan alumni dan data alumni yang cukup banyak, tetapi data tersebut kurang dimaksimalkan karena tidak diolah lebih lanjut untuk menjadi informasi dan pada saat ini khususnya bagi kalangan mahasiswa kurang mengetahui informasi persebaran alumni secara spesifik karena belum adanya sistem yang melakukan hal tersebut. Untuk mengatasi permasalahan tersebut dapat memanfaatkan teknologi Geographic Information System (GIS), dimana GIS memiliki kemampuan untuk menyajikan informasi dalam bentuk grafis dengan menggunakan peta sebagai antar muka, sehingga persebaran alumni dapat diketahui secara spesifik. Penelitian ini bertujuan untuk mengembangkan Sistem Informasi Data Alumni Berbasis Website GIS (Geographic Information System) Pada Politeknik Sains dan Teknologi Wiratama Maluku Utara. Penelitian ini dilaksanakan dikampus Politeknik Sains dan Teknologi Wiratama Maluku Utara. Pengumpulan data penelitian menggunakan dokumentasi dan wawancara. Hasil penelitian ini dapat membantu dan mempermudah mahasiswa wiratama untuk mengetahui sistem persebaran alumni wiratama.
\end{abstract}

Kata Kunci : Sistem Informasi, Data Alumni, Berbasis Web GIS

\begin{abstract}
Alumnus Data Distribution Information System Based on GIS Website (Geographic Information System) at the North Maluku Wiratama Science and Technology Polytechnic. The North Maluku Wiratama Polytechnic of Science and Technology is a Private campus located in Ternate City, Jati Ternate District, South Ternate, which annually has a large number of alumni graduates and alumni data. However, the data is not maximized because it is not processed more further to be informed and, mainly, for students not knowing information about alumni's specific distribution. After all, there is no system to do this. To overcome these problems, we can utilize Geographic Information Systems (GIS) technology, where GIS can present information in graphical form using maps as an interface so that alumni's distribution can be explicitly known. This study aims to develop a GIS Web-Based Alumni Data Information System (Geographic Information System) at the North Maluku Wiratama Science and Technology Polytechnic. This research was carried out at the North Maluku Wiratama Science and Technology Polytechnic. Research data collection using documentation and interviews. This study's results can help and make it easier for Wiratama students to find out the distribution systems of Wiratama alumni.
\end{abstract}

Keywords: Information Systems, Alumni Data, Gis Web-Based 


\section{PENDAHULUAN}

Sistem Informasi Geografis merupakan Sistem Informasi berbasis komputer yang menggabungkan antara user peta Geografis dan Informasinya tentang peta tersebut data (atribut) yang dirancang untuk mengelola, memanipulasi, analisis, memperagakan dan menampilkan data spasial untuk meyelesaikan perencanaan,mengelola dan meniliti permasalahn. Sistem Informasi Geografis (SIG) akhir-akhir ini mengalami perkembangan seiring kemajuan informasi. perkembangan sangat pesat saat ini membuat arus kebutuhan dalam dunia teknologi informasi turut berkembang cepat. Internet sebagai salah satu media untuk mendapatkan informasi juga semaikn mudah diakses darimana saja.

Dengan perkembangan teknologi internet, masyarakat semakin di mudahkan dalam melakukan segala fasilitas dan proses. Salah satu contohnya adalah mencari lokasi atau alamat persebaran alumni menggunkan SIG. Berdasarkan pemaparan tersebut, penulis melakukan pengamatan pada kampus Poltek Wiratama tentang persebaran data alumni belum terdata dengan baik. Belum adanyan manajemen yang menyediakan suatu sistem dan dapat mewadahi interaksi antara pihak institusi Wiratama dengan alumninya. Sehingga pihak Poltek Wiratama belum memiliki dokumentasi data sebaran alumni yang lengkap dan teratur.

Politeknik Sains dan Teknologi Wiratama Maluku Utara merupakan kampus swasta yang beralamat di Jalan Jati Lurus (Belakang Tower Trans TV), Kelurahan Jati Kota Ternate Selatan. Setiap tahun memiliki lulusan alumni dengan data yang cukup banyak. Namun data tersebut belum dimaksimalkan karena tidak diolah lebih lanjut untuk menjadi informasi. Sehingga saat ini, khususnya bagi kalangan mahasiswa kurang mengetahui data alumni secara spesifik. Karena belum adanya sistem yang mengelola data menjadi informasi.

Berdasarkan permasalahan tersebut maka, penulis merancang program dengan memanfaatkan teknologi menggunakan aplikasi Sistem Informasi Geografis (SIG). Berdasarkan uraian tersebut penulis merumuskan judul dalam karya tulis ilmiah yakni, "Sistem Informasi Persebaran Data Alumni Berbasis Website GIS (Geogrphic Information Sytem) pada Politeknik Sains dan Teknologi Wiratama Maluku Utara”.

\section{Tujuan Penilitian}

Tujuan penilitian ini adalah Merancang Sistem informasi Persebaran data Alumni Berbasis Website GIS (Geographic information System) pada Politeknik sains dan Teknologi Wiratama Maluku Utara.

\section{Rumusan Masalah}

Berdasarkan uraian latar belakang tersebut, maka penulis merumuskan masalah sebagai berikut: "Bagaimanakah merancang Sistem Informasi Persebaran data Alumni Berbasis Website GIS (Geographic Information System)"

\section{Manfaat Penilitian}

Adapun manfaat penilitian ini adalah sebagai berikut:

1. Dalam penilitian ini dapat memberikan acuan pengetahuan informasi terhadapa mahasiswa tentang persebaran alumni Politeknik sains dan Teknologi Wiratama; 
2. Dapat mengetahui alamat lokasi atau titik persebaran alumni-alumni Politeknik Sains dan Teknologi wiratama;

3. Dengan adanya Sistem Informasi Persebaran Alumni Berbasis Website GIS (Geographic Information System) pihak akademi/kampus Poltek Wiratama dapat terbentuk adanya sistem yang telah dibuat.

\section{Tinjauan Pustaka}

pada penilitian yang dilakukan oleh Irfan Tri Anggoro, Arief Laila Nugraha, Moehammad Awaluddin (2019) yang berjudul Sistem Informasi Alumni Berbasis GIS (Studi Kasus: Fakultas Teknik Universitas Halu Oleo). Aplikasi ini diharapkan dapat membantu pihak fakultas dan alumni dalam mengelola dan menyajikan informasi yang berkaitan dengan data alumnin Fakultas Teknik Universitas Halu Oleo sehingga dapat memberikan manfaat bagi semuah pihak. Sistem informasi dapat memudahkan alumni dan pengunjung untuk mendapatkan informasi berita, pengumuman dan lowongan pekerjaan.

Pada penelitian yang telah dilakukan oleh Adi Panca Saputra Iskandar, I Kadek Dwi Gandika Supartha (2019) Pengelolaan sumberdaya manusia merupakan hal yang mendukung visi dan misi ikatan alumni dengan cara membentuk relationship antar alumni agar dapat memberikan informasi mengenai tempat kerja dan peluang pekerjaan antara satu alumni dengan alumni lainnya. Dengan demikian, setiap alumni dapat saling bertukar informasi secara efektif. Berdasarkan pengujian menggunakan metode black box testing pada Sistem Informasi Geografis Pemetaan Persebaran Alumni didapatkan hasil bahwa semua modul dalam sistem telah berfungsi dengan baik dan dapat menampilkan informasi sesuai dengan yang dirancang.

\section{LANDASAN TEORI}

\section{Sistem}

Pengertian sistem adalah suatu jaringan kerja dari prosedur-prosedur yang saling berhubungan, berkumpul bersamasama untuk melakukan kegiatan atau untuk melakukan saran tertentu. (Huthaean, 2014).

\section{Sistem Informasi}

Sistem Informasi menurut Kismiaji (2015) Sistem informasi adalah cara-cara yang diorganisasi untuk mengumpulkan memasukan, dan mengelolah serta menyimpan data, dan cara-cara yang diorganisasi untuk menyimpan, mengelolah, mengendalikan, dan melakukan informasi sedemikian rupa sehingga sebuah organisasi dapat mencapai tujuan yang telah ditetapkan

\section{Sistem Informasi Geografis}

Geografis adalah ilmu yang mempelajari permukaan bumi dengan menggunakan pendekataan keruangan, ekologi, dan kompleks wilayah.Fenomena yang diamati merupakan dinamika perkembagan dan pembangunan wilayah yang ada dalam keseharian, misalnya informasi mengenai letak dan peresabaran dari kejadian-kejadian alamiah maupun fenomena terdapatnya sumber daya. Ketersediaan data yang bersifat geografi, dimana memiliki atribut utama keruangan, akan memudahkan banyak keuntungan. Sistem Informasi Geografis (bahasa inggris: Geographic Information System GIS) adalah sistem informasi khusus yang mengelola data yang memiliki informasi spasial (bereferensi keruangan). Atau 
dalam arti yang lebih sempit, adalah sistem komputer yang memiliki kemampuan untuk membangun, menyimpan, mengelola dan menampilkan informasi bereferensi geografis, misalnya data yang didentifikasi menurut lokasinya, dalam sebuahdatabase.(http://id.wikipedia.org/wi ki/Sistem_informasi_geografis).

\section{Google Maps}

Google Maps adalah jasa peta gratis dan online disediakan oleh google yang dapat ditemukan di https://maps.google.com. Pada situs tersebut kita dapat melihat informasi geografis pada hampir semua wilayah di muka bumi. Layanan ini interaktif, karena di dalamnya peta dapat digeser sesuai keinginan pengguna, mengubah tingkat zoom, serta mengubah tampilan peta. google maps juga menawarkan peta yang dapat diseret dan gambar setelit untuk seluruh dunia, serta menawarkan rute perjalanan.

\section{Xampp}

Madcoms (2016) Xampp adalah sebuah paket kumpulan software yang terdiri dari Apache, MySQL, PhpMyadmin, PHP, Perl, Filezilla, dan lain-lain. Winarno dkk (2014) Xampp adalah software web server yang biasa dipakai untuk mengakomodasi sistem operasi yang anda pakai (X), Apache (A), MySQL (M), PHP (P) dan Perl (P). Berdasarkan uraian tersebut disimpulkan bahwa xampp merupakan gabungan software web server yang didalamnya meliputi Apache, MySQL, PhpMyadmin, PHP, Perl, Filezilla, untuk mengakomodasi system yang dipakai.

\section{PHP MyAdmin}

Madcoms (2016) "PhpMyadmin adalah sebuah aplikasi open source yang berfungsi untuk memudahkan manajemen MySQL". Menurut Nugroho (2013) PhpMyAdmin adalah tools yang dapat digunakan dengan mudah untuk memanajemen databasa MySQL, sehingga kita tidak perlu lagi harus menulis query SQL setiap akan melakukan perintah operasi database

\section{MySQL.}

Winarno dkk (2014) "MySQL merupakan tipe data relasional yang artinya MySQL menyimpan datanya dalam tabel-tabel yang saling berhubungan". Berdasarkan teori tersebut simpulkan bahwa MySQL adalah suatu software atau program yang digunakan untuk membuat sebuah database yang bersifat open source.

\section{METODE PENELITIAN \\ Metode pengumpulan data}

Pengumpulan adata melalui dokumentasi dan wawancara kepada kepala biro akademik Politeknik sains dan Teknologi Wiratma Maluku Utara. Dokumentasi bertujuan untuk memperoleh data-data alimni Politeknik sains dan teknologi wiratama Maluku Utara.hasil wawancar bertujuan untuk memperoleh informasi terkait data alumni yang dijadikan data alumni pada penilitian ini.

\section{Bahan Dan Alat}

Bahan yang digunakan adalah:

1. Sistem Operasi windows

2. Microsoft Office untuk membuat olahan data

3. Microsoft Visio untuk menggambar atau membuat flowchart dan alur program

4. Browser untuk mengaksest program 
5. Google Maps API untuk pemeteaan server lokasi

6. Notepad untuk mengedit text dan scrip kode-kode pemograman

7. $H T M L, C S S, P H P$, digunakan sebagai Bahasa pemograman yang dipakai dalam Website.

8. Xamp sebagai server penghubung Alat yang digunakan adalah:

1. Processor Intel (R) Core (Tim) 132365M CPU@1.40GHz 140GHZ RAM 4.00GB type 32-bit ST500LT012-gws142 ATA;

2. printer canon IP2770 dan Printer Epson L120

3. flasdisk digunakan untuk menyimpan file

\section{Metode Analisis}

Metode analisis sistem yang digunakan adalah metode pendekatan terstruktur dimana sistem yang berjalan dan diusulkan menggunakan flowchart. Sedangan pada perancangan sistem peniliti menggunakan metode pendekatan berorientasi objek dangan cara menggambar sistem usulan menggunakan use case diagaram,actifity diagram,sequence diagram dan clas disagram.

\section{Metode pengembangan sistem}

Metode pengembangan pembuatan sistem peresbaran data alumni menggunakan metode prototyping. Metode prototyping merupakan metode pengembangan yang sangat cepat dan pengujin model kerja aplikasi baru yang dilakukan cara berulang-ulang, jika terjadi kesalahan pada sistem dapat diulang kembali pada tahap awal.

berikut merupakan tahapan-tahapan model prototyping:

1. Pengumpulan Kebutuhan pengumpulan data yang dilakukan dengan cara dokumentasi sebagai data pendukung data alumni dan wawancara dilakukan sebagai data pendukung kebutuhan sistem yang dibuat;

2. Membangun Prototyping

Dalam membangun prototyping peneliti menggunakan alat bantu flowchart sistem yang berjalan dan sistem diusulkan dengan menggunakan pendekatan terstruktur dan pendekatan berorientasi objek untuk membuat perancangan sistem Login, Dashboard, Data Mahasiswa, Data Jurusan, Data Laporan, Data User dan Logout;

3. Menggunakan Sistem.

Peneliti melakukan evaluasi sistem digunakan pengembangan sistem oleh pengguna apakah prototyping yang sudah dibangun sudah sesuai dengan keinginan pengguna;

4. Mengkodekan Sistem.

Dalam mengkodekan sistem, bahasa pemograman yang peneliti gunakan adalah HTML (HyperText Markup Languange) adalah tag-tag bahasa pemograman digunakan untuk mendesain halaman web serta mengatur struktur website, CSS (Cascading Style Sheet) adalah bahasa pemograman yang mempercantik tampilan halaman web, PHP (Hypertext Preprocessor) adalah bahasa pemograman yang dipakai untuk membuat situs web yang ditanamkan atau disipkan kedalam html/php, Maps API adalah Aplikasi Programming Interface yang digunakan untuk membuat program peta dengan bantuan java skrip tanpa harus menggambar peta, dan google maps untuk membuat titik kordinat dan koordinat; 
5. Menguji Sistem.

Pengujian sistem menggunakan metode black box, adalah metode pengujian perangkat yang menguji fungsionalitas yang betentangan dengan struktur internal atau kerja. Pengujian dilakukan dengan cara menyimpulkan kejadian sistem didterima dan ditolak.

6. Evaluasi Sistem:

Pelanggan mengevaluasi apakah sistem yang sudah jadi sudah sesuai dengan yang diharapkan. Jika ya langkah 7 dilakukan

7. Evaluasi Prototyping

Perangkat lunak yang telah diuji dan diterima pelanggan siap untuk digunakan. Jika tidak ulangi langkah 4 dan 5 .

\section{ANALISIS DAN PERANCANGAN}

Diawali dengan biro akma mebuat daftar data alumni Politeknik Sains dan Teknologi Wiratama Maluku utara,biro akma menyimpan data alumni disimpan dalam bentuk arsip dokumen.

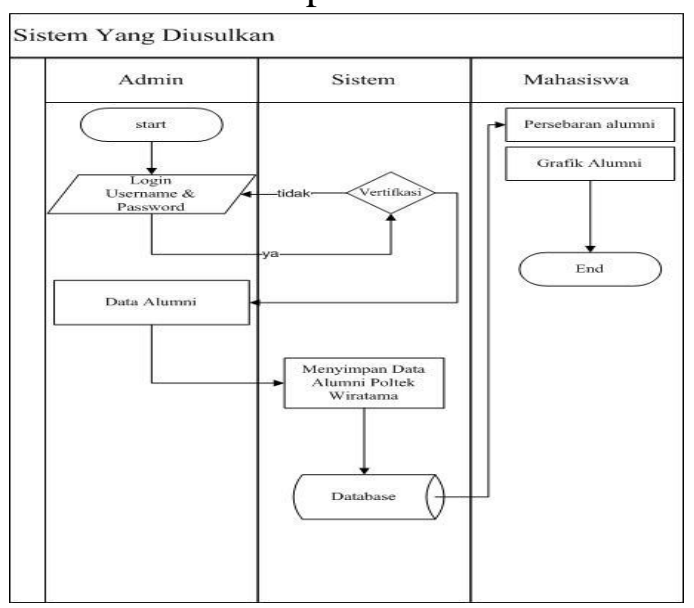

Gambar 1.Analisis Sistem yang diusulkan

\section{Rancangan Tabel}

Tabel 1. Tabel Data Mahasiswa

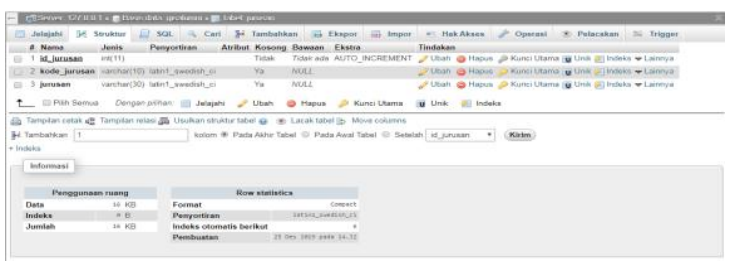

Tabel 2. Tabel Data Jurusan

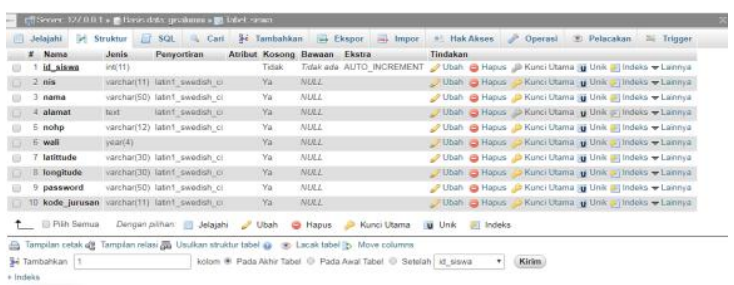

Tabel 3.Tabel data User

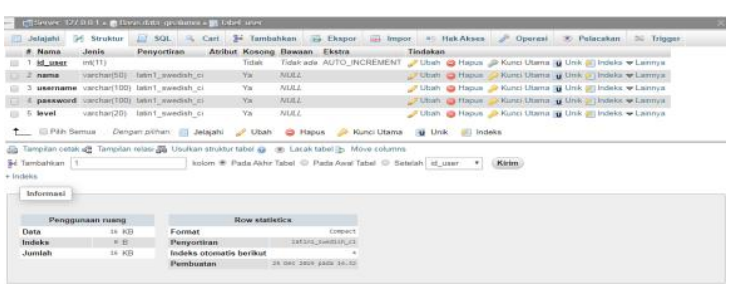

\section{Use Case Diagram}

Use case merupakan rancangan awal sistem informasi dimana terdapata actor yang merupakan fungsioanl yang berhubungan langsung dengan sistem.

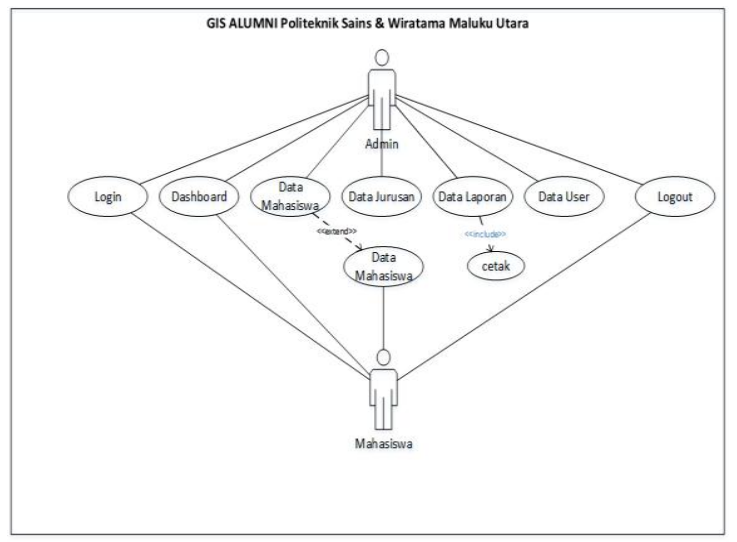

Gambar 2. Use case

\section{Activity Diagram}




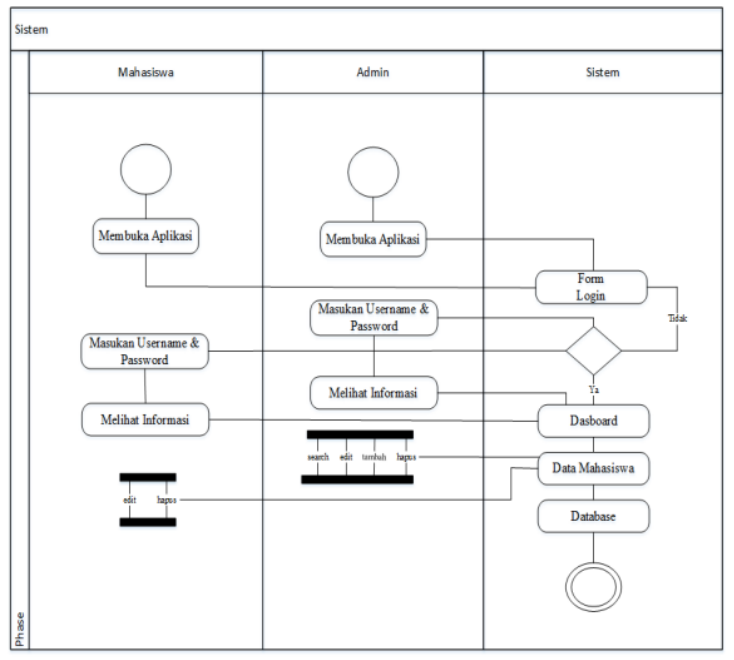

Gambar 3.Activity diagaram kelola data mahasiswa

\section{Class diagram}

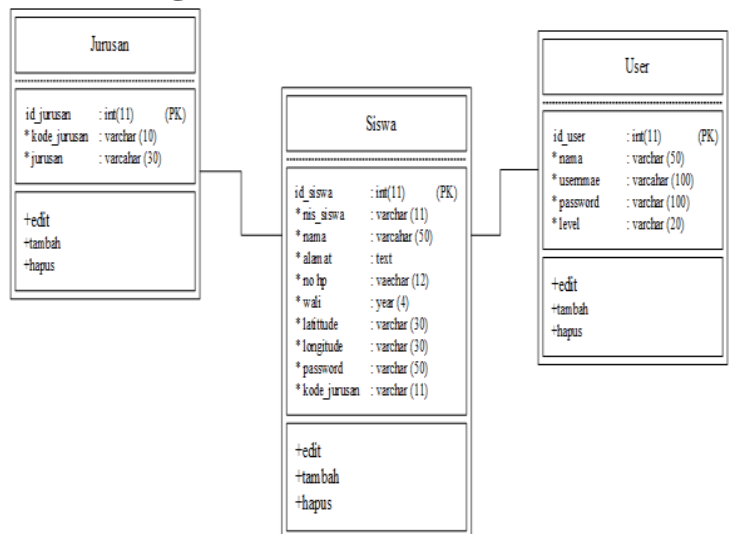

Gambar 4. Class diagaram

\section{IMPLEMENTASI DAN PEMBAHASAN}

Tampilan Menu Login dan Mahasiswa

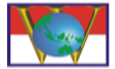

Politeknik Sains \& Teknologi Wiratama

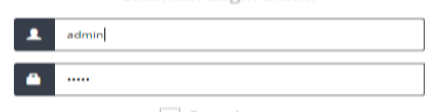

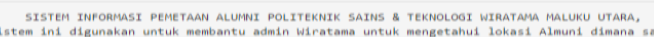

Gambar 5. Tampilan menu login admin dan mahasiswa.

Halaman login digunakan untuk masuk ke menu utama masukan username dan password.
Tampilan Menu Beranda Admin

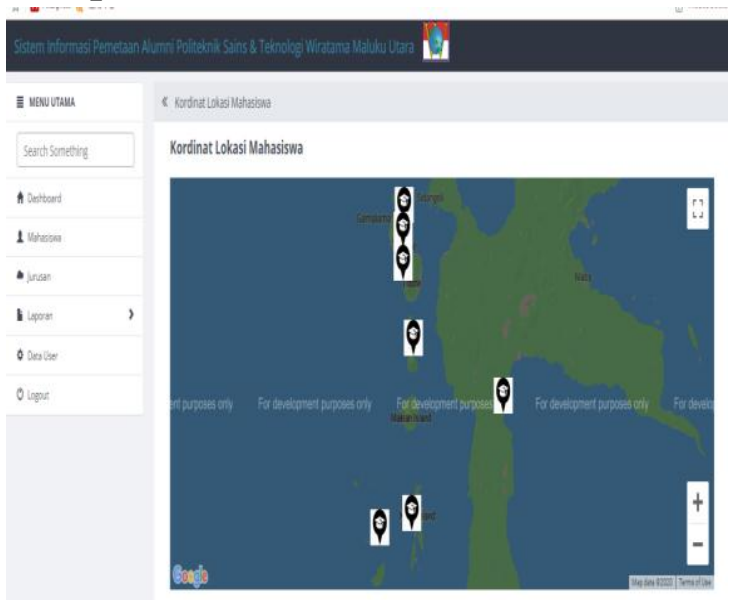

Gambar 6. Tampilan menu beranda admin terdiri dari menu Data Dashboard, Data Mahasiswa, menu Data Jurusan, Data Laporan, Data User, dan menu Logout. Pada menu beranda ini ditampilkan peta lokasi persebaran alumni sehingga user dapat melihat jika ada perubahan penambahan data alumni yang dilakukan oleh user.

\section{Tampilan Menu Admin data Mahasiswa}

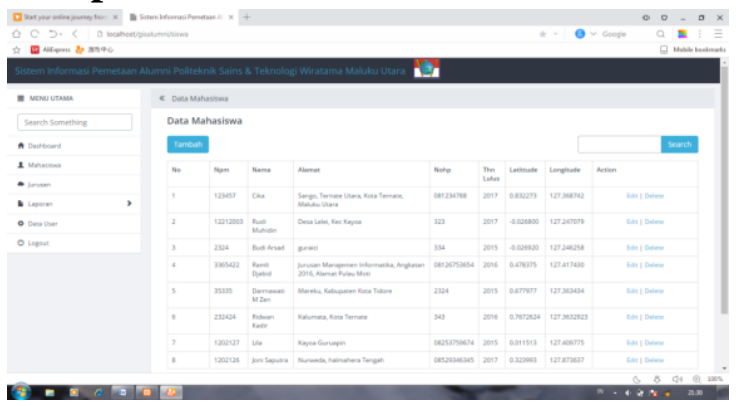

Gambar 7.Tampilan menu admin data mahasiswa.

Halaman ini menampilkan data dari tabel data mahasiswa, untuk menambah data mahasiswa pilih tombol tambah, untuk mengubah data mahasiswa pilih tombol edit, untuk menghapus data pilih tombol delete.

\section{Tampilan Menu Admin data Jurusan}




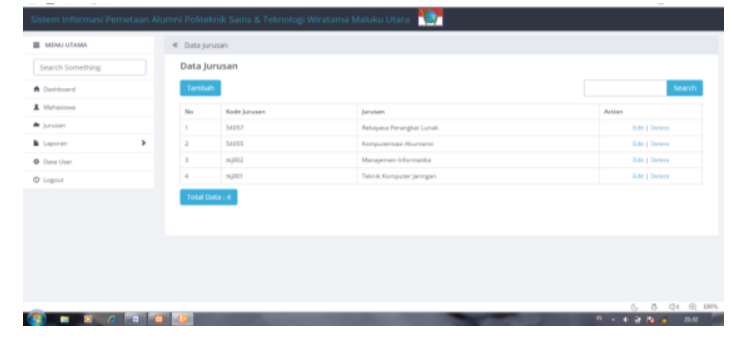

Gambar 8. Tampilan menu admin data jurusan.

Data jurusan menampilkan data dari tabel jurusan, untuk menambah data klik tombol tambah, untuk mengubah data jurusan klik tombol edit, untuk menghapus data jurusan klik tombol delete.

\section{Tampilan Menu Admin data Laporan}

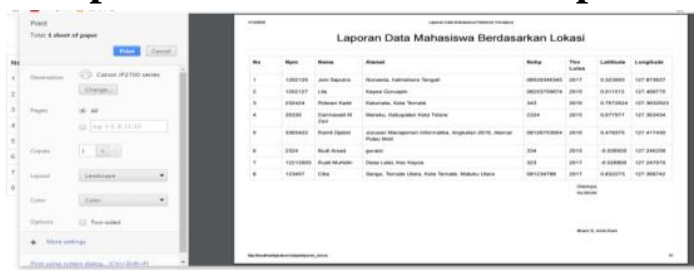

Gambar 9. Tampilan menu admin data laporan.

digunakan oleh admin untuk melihat atau mencetak laporan berdasarkan lokasi atau alamat data alumni Politeknik Sains dan Teknologi Wiratama Maluku Utara.

\section{Tampilan Menu Admin data User}

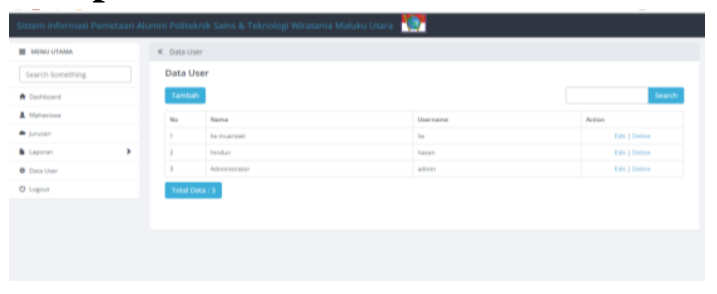

Gambar 10. Tampilan menu admin data user.

Halaman data user menampilkan data dari tabel data user, untuk menambah data user pilih tombol tambah, untuk mengubah data user pilih tombol edit, untuk menghapus pilih tombol delete.

Tampilan Menu Beranda Mahasiswa

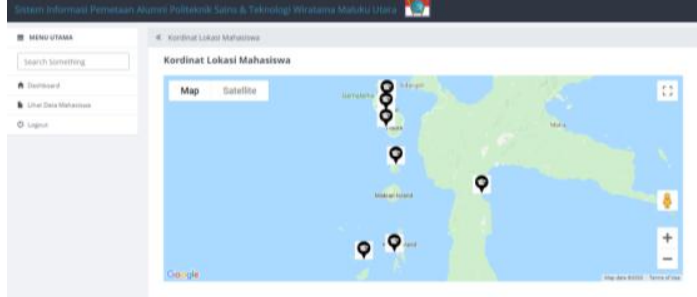

Gambar 11.Tampilan menu beranda mahasiswa.

Halaman beranda ini terdapat menu dashboard, menu lihat data mahasiswa, dan menu logout.

\section{Tampilan Menu Dashboard data Mahasiswa}

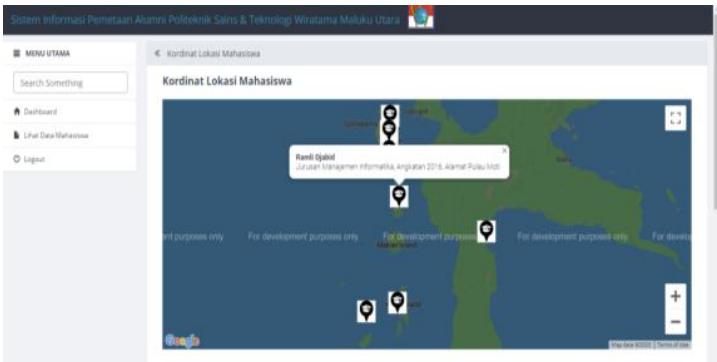

Gambar 12.Tampilan menu dashboard mahasiswa dapat melakukan pencarian secara langsung lokasi persebaran alumni yang sudah tersimpan didalam sistem, dengan cara mengklik salah satu tombol combo maka akan menampilkan nama, jurusan angkatan, dan alamat alumni tersebut.

\section{Tampilan Menu Grafik Mahasiswa Perjurusan}

우

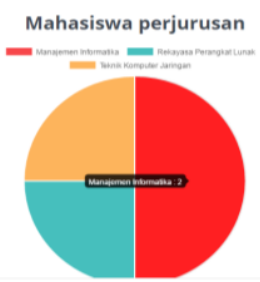

Gambar 13. Tampilan grafik mahasiswa

Dengan keterangna garafik, warna orange jurusan Teknik Komputer Jaringan warna biru jurusan Rekayasa Perangkat 
Lunak dan warna merah jurusan Manajemen Informatika.

Tampilan Menu Mahasiswa Lihat data Mahasiswa

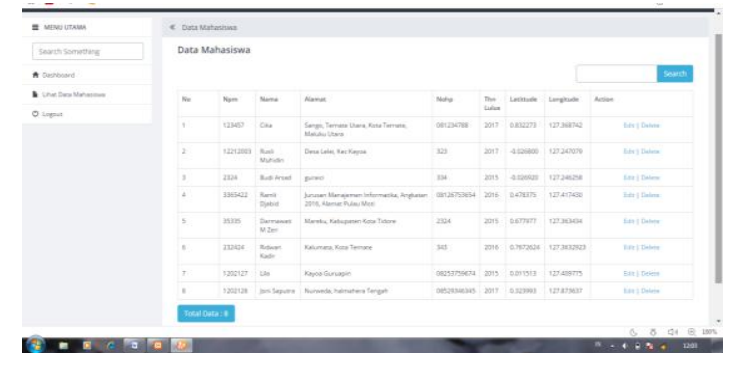

Gambar 14. Tampilan menu lihat data mahasiswa.

Menampilkan data dari tabel data mahasiswa, untuk mengubah data mahasiswa pilih tombol edit, untuk menghapus data pilih tombol delete.

\section{Pengujian Sistem}

Pengujian sistem informasi persebaran data alumni Berbasis Website GIS (Geogrphic Informatin System) pada Politeknik Sains dan Teknologi Wiratama Maluku utara menggunakan metode pengujian black box cara yang digunakan dengan menginput data tertentu dan mengamati hasil data yang didapatkan

\begin{tabular}{|l|l|l|l|}
\hline $\begin{array}{l}\text { N } \\
\text { o }\end{array}$ & $\begin{array}{l}\text { Skenario } \\
\text { Pengujian }\end{array}$ & $\begin{array}{l}\text { Hasil Yang } \\
\text { diharap }\end{array}$ & $\begin{array}{l}\text { Kesimpulan } \\
\text { (Diterima/D } \\
\text { itolak) }\end{array}$ \\
\hline 1. & $\begin{array}{l}\text { Masukan } \\
\text { username dan } \\
\text { password, } \\
\text { lalu klik } \\
\text { tombol login } \\
\text { Test } \\
\text { pengujian : } \\
\text { menerima } \\
\text { dan masuk } \\
\text { ke } \\
\text { menu } \\
\text { utama } \\
\text { Hasil } \\
\text { pengujian : }\end{array}$ & Diterima \\
\hline 2. & $\begin{array}{l}\text { Masukan } \\
\text { username dan } \\
\text { mengkosongk } \\
\text { an password, } \\
\text { lalu klik } \\
\text { tombol login }\end{array}$ & $\begin{array}{l}\text { Sistem } \\
\text { menolak } \\
\text { dan } \\
\text { menampilk } \\
\text { an pesan } \\
\text { username }\end{array}$ & Ditolak \\
\hline
\end{tabular}

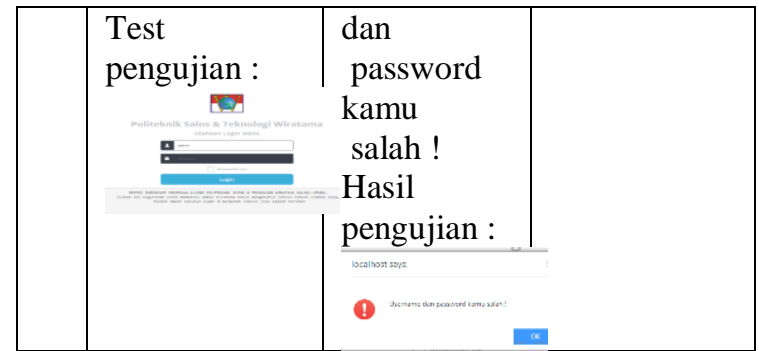

\section{KESIMPULAN}

Berdasarkan hasil pembahasan yang diperoleh selama penelitian tentang Sistem Informasi Persebaran Data Alumni Berbasis Website GIS (Geographic Information System) Pada Politeknik Sains dan Teknologi Wiratama Maluku Utara. Disimpulkan sebagai berikut :

1. Sistem yang dirancang menampilkan informasi tentang persebaran data alumni Poltek Wiratama Maluku Utara.

2. Persebaran alumni dilakukan dengan cara menyalin longitut dan longtitut untuk mendapatkan koordinat $\mathrm{X}, \mathrm{Y}$ data diri dari tiap alumni yang tersebar di berbagai daerah menggunakan google maps untuk dibuat data peta persebaran alumni.

3. Mempermudah mahasiswa mengetahui persebaran alumni Poltek Wiratama Maluku Utara.

\section{Saran}

Berdasarkan hasil penilitian perancangan Sistem informasi Persebaran Data Alumni Berbasis Website GIS (Geographic Information System) pada Politeknik Sains dan Teknologi Wiratama Maluku Utara di temukan beberapa hal sehingga peniliti mengajukan beberapa saran untuk peneliti mendatang diantaranya:

1. Sistem perlu menambah tampilan atau fitur-fitur persebaran alumni seperti 
penambahan foto profil, serta penambahan data pekerjaan yang akan diinput oleh alumni tersebut.

2. Sistem ini belum membatasi tabel lihat data mahasiswa agar mahasiswa tidak perlu melakukan semuah edit dan hapus data alumni yang ada, pada tabel laporan perlu penambahan laporan pertahun dan perangkatan, dan perlu penambahan pencarian data berdasarkan angkatan/tahun.

\section{DAFTAR PUSTAKA}

Adi Panca Saputra Iskandar, I Kadek Dwi Gandika Supartha, Sistem Informasi Geografis Pemetaan Sebaran Alumni pada STIMIK STIKOM Indonesia JCOSINE, E-ISSN: 2541-0806 PISNN: 2540-8895 Vol. 3, No. 2, Desember 2019

Firman Teguh Wibowo, Ika Purwanti Ningrum Purnama, Bambang Pramono. Sistem Informasi Alumni Berbasis GIS (Studi Kasus: Fakultas Teknik Universitas Halu Oleo), Seman TIK, ISSN: 2502-8928 (online) vol.2, No.2, Jul-Des 2016,pp.37-46

Arifandy Mario Mamonto, Darman Umagapi, A Ambarita, Perancangan Aplikasi GIS Lokasi Pariwisata Di Pulau Morotai, IJIS - Indonesian Journal On Information System Vol 5 No 1, eISSN 2548-6438, pISSN 2614-7173, https://doi.org/10.36549/ijis.v5i1.67

A Ambarita, 2020, Analisys dan pengembangan sistem informasi: pendekatan model driven, Gosyen Publishing, Yogyakarta

Hutahaean, Jeperson, 2014, Konsep Sistem Informasi. Yogyakarta: Deepublish.

Krismiaji, 2015, Sistem Informasi Akutansi.Edisi Keempat, UPP STIM YKPN Yogyakarta.

Muharto, A Ambarita, 2016, Metode Penelitian Sistem Informasi: Mengatasi Kesulitan Mahasiswa dalam Menyusun Proposal

Penelitian, Deepublish. Yogyakarta

Matcoms, 2016, Sukses Membangun Toko

Online dengan PHP dan MySQL. Yogyakarta, Andi

Winarno, dkk , 2014, 24 Jam Belajar PHP. Jakarta: Elese Media Komplitindo. 